\title{
High-resolution Biostratigraphic Studies of Step-1 Well, Offshore, Western Niger Delta
}

\section{Visoko resolucijske biostratigrafske preiskave morske vrtine Step-1 na območju zahodne delte reke Niger}

\author{
M. E. Nton* and S. O. Famori* \\ Department of Geology, University of Ibadan, Ibadan, Nigeria \\ *Corresponding author: E-mail: ntonme2009@gmail.com, sfamori@yahoo.com
}

\begin{abstract}
A high-resolution biostratigraphic study of the STEP-1 well, offshore Western Niger Delta Basin, Nigeria, was carried out using foraminifera, calcareous nannofossils and palynomorphs. The study was aimed at identifying the biostratigraphic zones, age deductions as well as palaeoenvironmental and palaeoclimatic reconstructions. From the studied well section of $609 \mathrm{~m}(1,829-2,438 \mathrm{~m}), 50$ ditch cuttings were used for foraminifera and calcareous nannofossils, while 25 samples were used for palynological studies at $12 \mathrm{~m}$ and $24 \mathrm{~m}$ intervals, respectively. Standard laboratory preparation techniques were employed for the three microfossil groups. Due to the occurrence of some forms such as Globigerina praebulloides, Haplophragmoides spp, Bolivina scalprata miocenica, Valvulina flexilis and Cyclammina cf. minima, two planktonic and one benthonic foraminifera zones were identified as follows: Lower N18, Upper N17 zone (early Pliocene, late Pliocene) and Cyclammina minima zone (late Miocene), respectively. Two biozones were recognized for the nannofossils and include NN12 (Ceratolithus cristatus zone) and NN11 (Discoaster berggrenii zone). These zones were assigned to early Pliocene and late Miocene, respectively. Other forms include Discoaster pentaradiatus, Sphenolithus abies and Ceratolithus armatus. Echitricolporites spinosus/ P800zone has been assigned for the Palynomorph assemblages and was dated late Miocene due to the quantitative occurrence of Cyperaceaepollis spp. Four identified major condensed sections include intervals at 1,926, 1,987, 2,097 and 2,316 m, which have been dated 5.0, 5.8, 6.3 and 7.0 Ma, respectively. Based on the benthonic foraminiferal species and Palynological Marine Index, a shallow marine environment is
\end{abstract}

deduced for the studied interval which was interpreted to be deposited under both wet and dry palaeoclimatic conditions. The findings, no doubt could serve as a template for a sequence stratigraphic model, generally beyond the resolution of seismic stratigraphy.

Keywords: drilling regime, roller cone bit, wear, reduced penetration rate, change of the material properties.

\section{Izvleček}

Z uporabo alg luknjičark, apnenčastih nanofosilov in palinomorf so bile na območju zahodne delte reke Niger izvedene visoko resolucijske biostratigrafske preiskave morske vrtine STEP-1. Namen preiskave je bilo prepoznavanje biostratigrafskih območij, starosti ter paleookoljskih in paleoklimatskih rekonstrukcij. Iz $609 \mathrm{~m}$ dolgega preiskovanega odseka vrtine (1829$2438 \mathrm{~m}$ ) je bilo uporabljenih 50 vzorcev za preiskave alg luknjičark ter apnenčastih nanofosilov ter 25 vzorcev za palinološke preiskave na intervalih dolžin $12 \mathrm{~m}$ in $24 \mathrm{~m}$. Uporabljene so bile standardne laboratorijske tehnike priprave za tri skupine mikrofosilov. Zaradi pojavljanja nekaterih oblik, kot so Globigerina praebulloides, Haplophragmoides spp, Bolivina scalprata miocenica, Valvulina flexilis in Cyclammina cf. minima sta bili identificirani dve planktonski ter ena bentonska cona alg luknjičark. To sta coni: lower N18, Upper N17 (zgodnji Pliocen, pozni Pliocen) in cona Cyclammina minima (pozni Miocen). Za nanofosile sta bili prepoznani dve bioconi, in sicer NN12 (cona Ceratolithus cristatus) in NN11 (cona Discoaster berggrenii). Omenjeni coni sta bili dodeljeni zgodnjemu Pliocenu ter poznemu Miocenu. Ostale forme vključujejo: Discoaster pentaradiatus, Sphenolithus 
abies in Ceratolithus armatus. Echitricolporites spinosus / cona P800 je bila dodeljena sklopom palinomorfa in je bila datirana kot pozni Miocen zaradi kvantitativnega pojavljanja Cyperaceaepollis spp. Štiri identificirani glavni zgoščeni odseki vključujejo intervale 1926 m, 1987 m, 2097 m in 2316 m, ki so bili datirani kot 5.0 Ma, 5.8 Ma, 6.3 Ma in 7.0 Ma. Na osnovi bentonske vrste alg luknjičark in palinološkega morskega indeksa, je plitvo morsko območje izbrano za preučevan interval ki je nastal pod mokrimi in suhimi paleoklimatskimi pogoji. Izsledki preiskave lahko brez dvoma služijo kot osnova za zaporedni stratigrafski model, ki v splošnem presega ločljivost seizmične stratigrafije.

Ključne besede: biostratigrafija, paleoklima, paleookolje, palinološki morski indeks

\section{Introduction}

The Niger Delta Basin is one of the rift-generated sedimentary basins on the continental margin of the Gulf of Guinea in Nigeria [1]. The study area lies approximately between latitudes $4^{\circ} 23^{\prime} 30^{\prime \prime} \mathrm{N}$ and $6^{\circ} 24^{\prime} 00^{\prime \prime} \mathrm{N}$ and longitudes $2^{\circ} 45^{\prime} 30^{\prime \prime} \mathrm{E}$ and $6^{\circ} 46^{\prime} 30^{\prime \prime} \mathrm{E}$ (Figure 1). As the Niger delta basin matures, most of its subsurface uncertainties lie at reservoir scale, and hence the need for application of biostratigraphy. Oil companies which invest hugely in this high-risk business of oil exploration have undoubtedly gained much from biostratigraphic studies. Apart from assigning ages to rocks, the prediction of water depths and palaeodepositional environments is vital for the understanding and deduction of depositional models with reasonable productiveness [2]. Previous studies include those on foraminifera biostratigraphy from offshore Western Niger Delta [3]. Fajemila [3] recognized five foraminiferal zones and inferred that the sediments were of normal salinity and belonged to early Pliocene to late Miocene age.

Sanuade [4] carried out calcareous nannofossil biostratigraphy of Well ' $\mathrm{K}-2$ ', in the deep offshore, Niger Delta. Two major zones were identified, while one condensed section was believed to be associated with 2.0 Ma maximum flooding surface (MFS).

Aturamu [6] reported on integrated biostratigraphic studies using foraminiferal and palynomorph assemblages within the Niger Delta. They established two planktonic foraminiferal zones, Globigerinoidies obliquus and Globigerinoides ruber, aged Miocene-Pliocene and four benthic foraminiferal biozones. They proposed Echiperioporities cf. estelae, Psilatricolpites okeizeis and Foeveotricolpites sp. palynological zones which are correlatable with the Pantropical zones. Ukpabi and Osterloff [7] integrated microflora and nannoflora for biostratigraphic and palaeoenvironmental study of the Niger Delta sediments. They documented the occurrence of Belskipolliselegans which revealed the influence of climate, sea-level changes and/or sediment influx in the Niger Delta during the middle Miocene. The transgressive and regressive trends were interpreted and correlated based on the general distribution of Belskipolliselegans within the palynological zones in the middle Miocene Agbada Formation of the Niger Delta Basin.

The present study gives an account of integrated foraminiferal, calcareous nannofossils and palynostratigraphy of the STEP-1 well, offshore western Niger delta, in order to deduce the age of the penetrated interval, and provide detailed information on the paleoenvironment of deposition and palaeoclimatic conditions of the sediments. Such information, no doubt, could serve as a sequence stratigraphic model, generally beyond the resolution of seismic stratigraphy.

\section{Geologic setting and stratigraphy}

The Niger Delta basin is situated between latitudes $3^{\circ}$ and $6^{\circ} \mathrm{N}$ and longitudes $5^{\circ}$ and $8^{\circ} \mathrm{E}$ in the Gulf of Guinea on the margin of West Africa, and is one of the largest deltaic systems in the world. Doust and Omatsola [8] and Short and Stauble [9] classified the subsurface Niger Delta into three stratigraphic units from the oldest to the youngest: Akata, Agbada and Benin Formations (Figure 2). The Akata Formation is the basal unit of the Tertiary Delta Complex and comprised shales, clays and silts at the base of the known delta sequence. They contain a few 


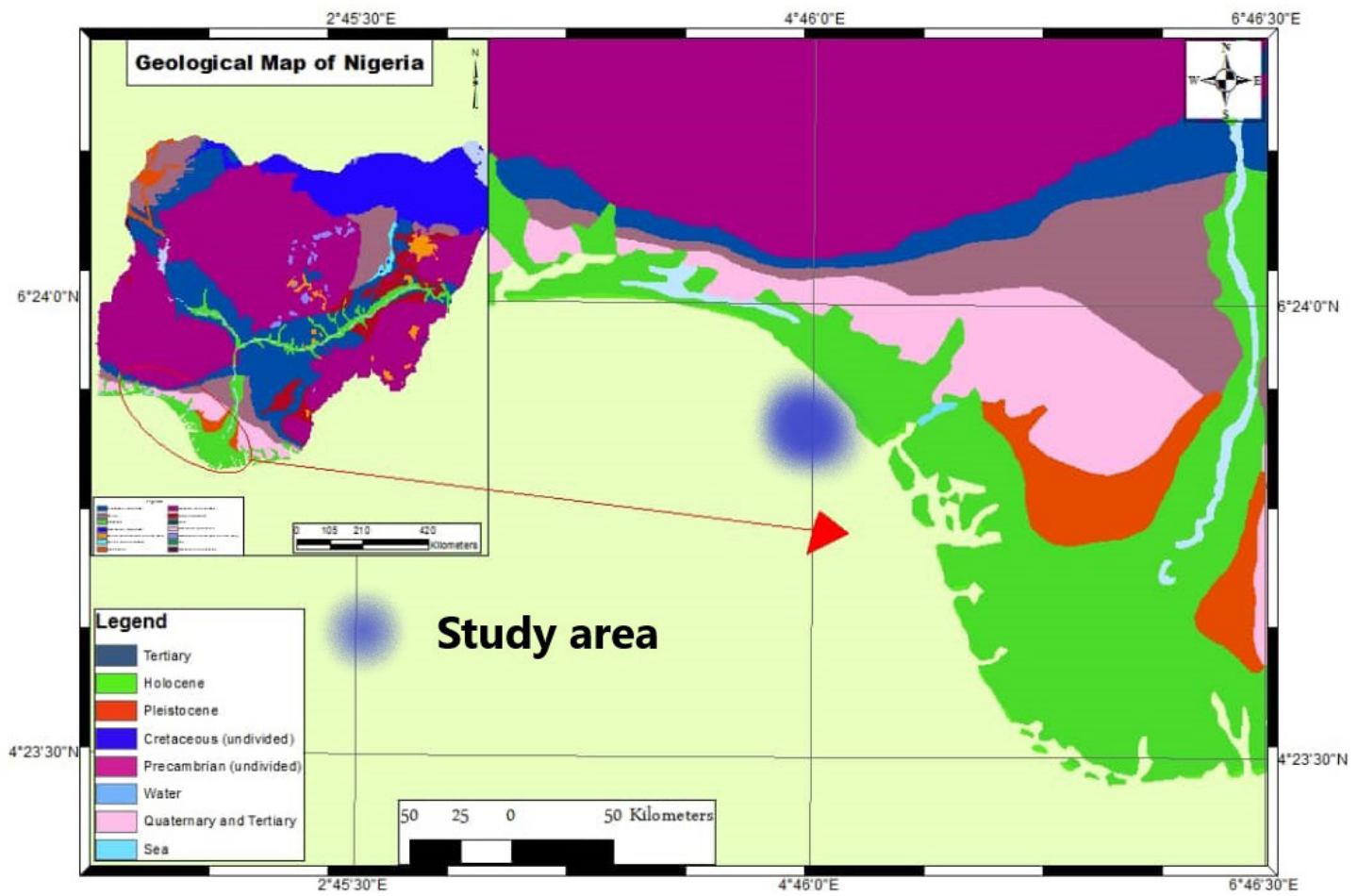

Figure 1: Geological map of Western Niger Delta showing the approximate study area (modified from [5]).

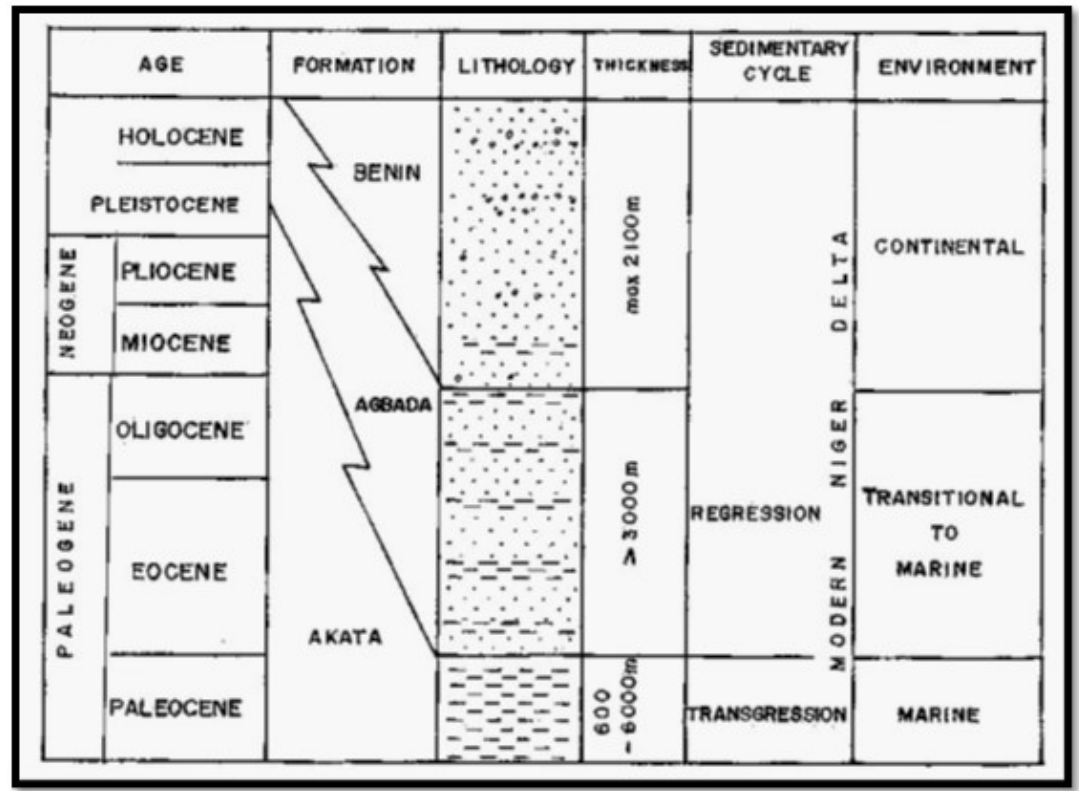

Figure 2: Stratigraphic succession of the Niger Delta [7].

streaks of sand, possibly of turbiditic origin [10]. The Agbada Formation is the hydrocarbon-prospective sequence, a paralic clastic sequence which lies above the Akata Formation. The upper part of the Agbada Formation often has sand percentages ranging from 50\% to $75 \%$, becoming increasingly sandy towards the overlying Benin Formation, while the basal part is more of shale sequence [8]. The Benin Formation is the freshwater-bearing formation in the Niger Delta. It comprises the top part of the Niger Delta Basin, from the Benin-Onitsha area in the north to beyond the present coastline [9]. 


\section{Materials and methods}

Materials used in this study include ditch cuttings and gamma ray log. Because of the proprietary nature of the well, the exact location information was not provided, hence it was code-named STEP-1 well. The samples were selected and composited at intervals of $12 \mathrm{~m}$ and $24 \mathrm{~m}$, respectively, which was then prepared and analysed based on fauna and flora contents. The biostratigraphic analyses were carried out while the other analysis was achieved using the STRATABUG software.

\section{Lithologic description}

The lithologic description was carried out by examining the samples under a hand lens in order to identify the constituents, describe and name the lithology. This was supported by the GR log to complement the lithologic description based on its deflection away from the Shale Baseline (SBL).

\section{Sample preparation}

The ditch cuttings were prepared for foraminifera, calcareous nannofossils and palynomorph contents using standard preparatory methods. Fifty samples were selected at $12 \mathrm{~m}$ intervals for foraminifera preparation; the standard weight ( $20 \mathrm{~g}$ ) of each sample was soaked overnight to ensure proper disaggregation and liberation of microfossils present within the cuttings. The disaggregated samples were then washed under a shower of water over a $63 \mu \mathrm{m}$ sieve, rinsed in liquid detergent to remove drilling mud and dried over a hot plate. The forms were picked with a picking needle under an Olympus binocular microscope. Preparation and identification of individual foraminifera were guided following the works of [11-13], among others.

Fifty samples were selected at $12 \mathrm{~m}$ interval for calcareous nannofossils; about $2 \mathrm{~g}$ of each of the samples were scraped onto a glass microscope slide. The slides were labelled sequentially and two blobs of Norland Optical Adhesive were affixed onto the cover-slip. The slides were dried and later studied under a transmitting light microscope in polarized light. This was done following Martini [14].
Twenty-five samples were selected and composited at $24 \mathrm{~m}$ intervals for palynological analysis. A constant weight ( $30 \mathrm{~g}$ ) of each sample was initially given a $5 \%$ dilute hydrochloric acid treatment to remove carbonates prior to complete digestion in concentrated hydrofluoric acid (HF) under a fume cupboard. The samples were decanted thrice at an interval of $1 \mathrm{~h}$ each through the Branson Sonifier and with the aid of a $5 \mu \mathrm{m}$ sieve to filter away the inorganic matter. A LOCTITE mounting medium was used for the residues, which are the palynomorphs. Identification and preparation of the specimen was done following Germeraad et al. [15].

\section{Results and discussion}

\section{Lithologic description}

The lithostratigraphic section of the studied well was produced from ditch sample descriptions and the deflection away from the shale base line on the gamma ray log. The total thickness of the analysed sample is $609.6 \mathrm{~m}$ (i.e. between $1,828.8 \mathrm{~m}$ and 2,438.4 $\mathrm{m}$ intervals). From the lithologic description, the samples are mainly shale with a little sand. The shale is fissile, greyish to black, while the sand is fine to medium grained. The observation revealed that the studied well is largely made up of a sequence of fine-grained shale alternating with fine- to medium-grained sandstone in the lower part while the upper part is mainly shale (Figure 3).

\section{Foraminifera biostratigraphy}

The well recorded fairly rich and diverse assemblages of planktonic and benthonic foraminifera at the upper part (1,902-2,109 m), with 55 species recorded. Of these, 22 (40\%) species are calcareous, while 27 (49\%) are arenaceous. Two foraminiferal "zones" were recognized in the studied section. The Cenozoic chronostratigraphic scheme of Berggreni et al. [13] and the Global Sequence Cycle Chart of Hardenbol et al. [16] were adopted for this study. The zones are characterized briefly below. \ 


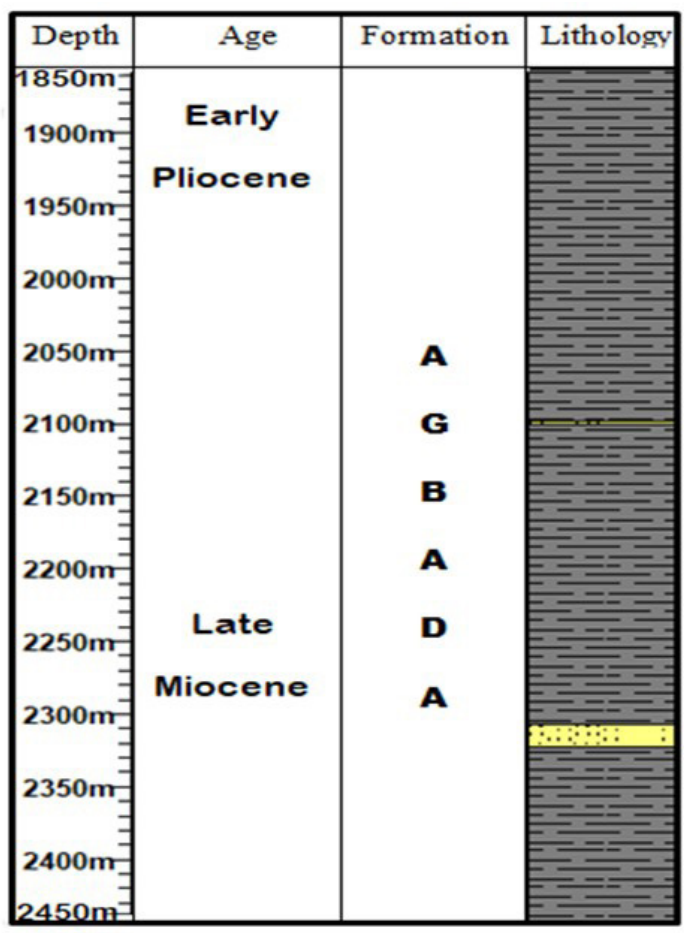

LEGEND

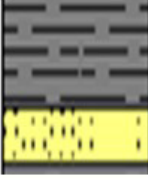

Shale

Sandstone

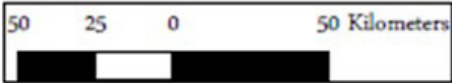

Figure 3: Lithological description of STEP-1 well.

\section{Globorotalia tumida/Cyclammina minima zone}

Stratigraphic interval: 1,841-1,987 m

Equivalent planktic foraminiferal zone: "Lower" N18-“Upper" N17 zone.

Age: Late Miocene (5.99-5.47 Ma)

Diagnosis: The top of this zone is placed at the 5.47 Ma MFS, recognized at $1,926 \mathrm{~m}$, while the base is defined by the 5.8 Ma MFS, recognized at 1,987 $\mathrm{m}$ (Figure 4). The First Downhole Occurrence (FDO) of the zonal marker, Cyclammina cf. minima was recorded at 1,926 $\mathrm{m}$ (Table 1). The zone correlates with the "Lower" N18-"Upper" N17 planktic foraminiferal zone of Berggreni et al.[13] and Hardenbol et al. [16]. The age is late Miocene.

\section{Globoquadrina dehiscens/Haplophragmoides} narivaensis zone

Stratigraphic interval: 1,987-2,438 m.

Equivalent planktic foraminiferal zone: "Middle-Lower" N17 zone.

Age: Late Miocene

Diagnosis: Undiagnosed

\section{Calcareous nannofossil biostratigraphy}

The results of calcareous nannofossil analysis show high abundance and diversity of species (Figure 5). Biozonation and age determination of the well was based largely on calcareous nannofossils assemblages, abundance and diversity. The chronostratigraphic scheme adopted follows the usage of the worldwide zonation schemes of Okada and Bukry [17] and Haq et al. [18]. Considerable effort was made to identify and define zonal tops with the FDOs of diagnostic marker species, abundance and species diversity peak as these form the most reliable events [14]. The highest nannofossil peaks were dated using important marker species such as Sphenolithus abies, Discoaster pentaradiatus, Ceratolithus cristatus, Ceratolithus armatus, Discoaster quinqueramus and Discoaster berggrenni (Table 2). The stratigraphic distribution of the recorded species along with the significant datum, MFSs, nannofossil zones and age interpretations are presented in distribution charts (Figure 5). The highlights of the results are summarized below. 


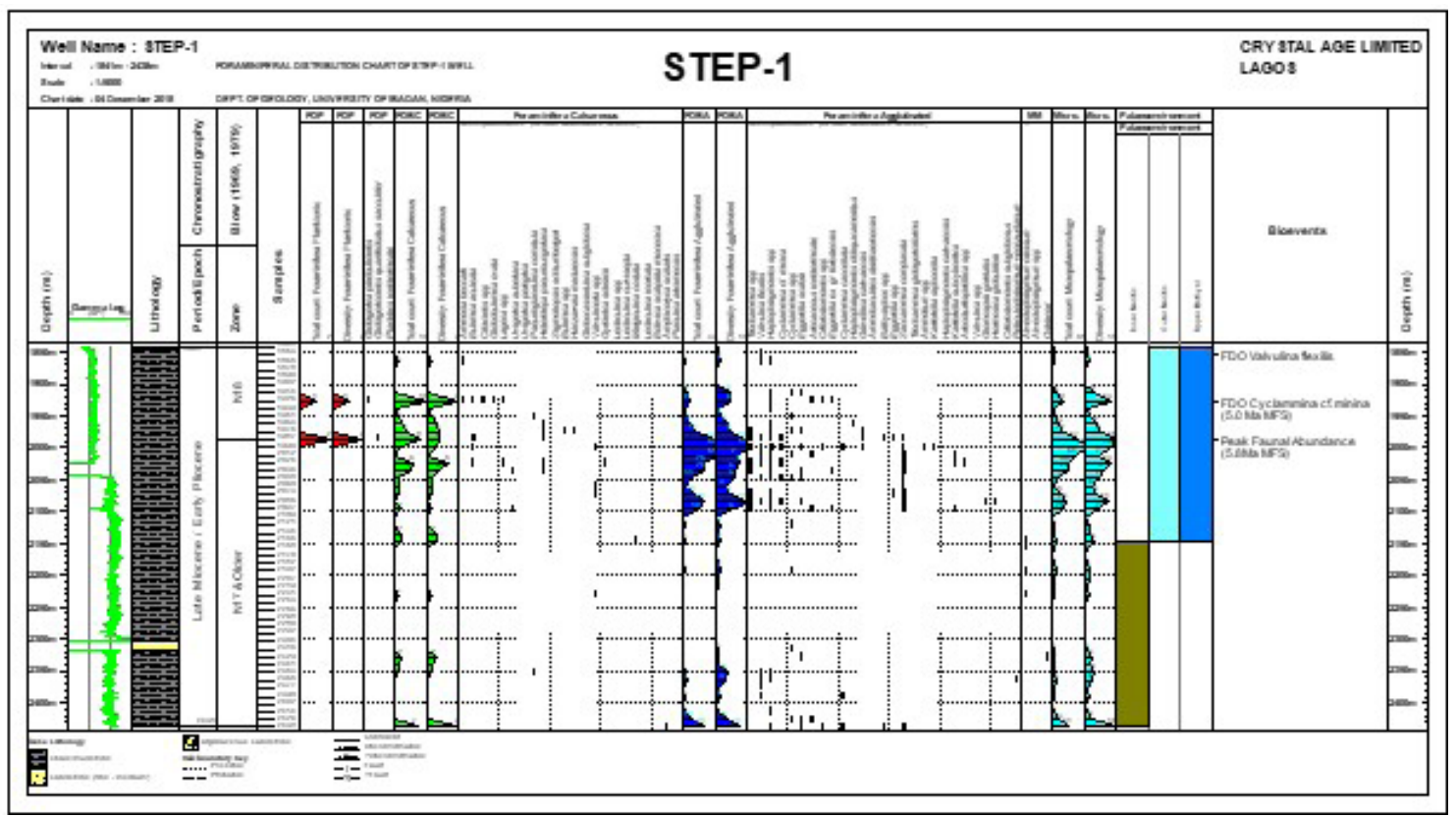

Figure 4: Foraminiferal distribution chart of STEP-1 well.

Table 1: Foraminferal biostatigraphy of STEP-1 well

\begin{tabular}{|c|c|c|c|c|}
\hline $\begin{array}{l}\text { Depth } \\
(\mathrm{m})\end{array}$ & Age & $\begin{array}{l}\text { Planktonic } \\
\text { zone }\end{array}$ & $\begin{array}{l}\text { Benthonic foram } \\
\text { zone }\end{array}$ & Bioevents \\
\hline 1,853 & \multirow{2}{*}{ Early Pliocene } & \multirow{2}{*}{ N18 } & \multirow{2}{*}{ Indeterminate } & FDO Valvulina flexilis \\
\hline 1,926 & & & & Cyclamina cf. minima 5.0 Ma MFS \\
\hline 1,987 & \multirow{3}{*}{ Late Pliocene } & \multirow{3}{*}{ N17 and older } & & \multirow{3}{*}{ Peak fauna abundance 5.8Ma MFS } \\
\hline 2,097 & & & $a$ & \\
\hline 2,438 & & & Indeterminate & \\
\hline
\end{tabular}

1. Interval: $1,841-1,926 \mathrm{~m}$

Zone: NN12

Age: Early Pliocene

Diagnosis: This interval is dated based on the presence of Ceratolithus cristatus at 1,902 m and the presence of Ceratolithus armatus at $1,914 \mathrm{~m}$. These records of nannofossils represent the early Pliocene.

2. Interval: $1,926-2,438 \mathrm{~m}$

Zone: NN11

Age: Late Miocene

Diagnosis: This interval is characterized by an increase in nannofossil abundance and diversity. Its nannofossil peak at 1,963 m represents the 5.8 Ma MFS [18] late Miocene NN11 zone. This is confirmed by the FDO of Discoster quinqueramus at $1,939 \mathrm{~m}$. The presence of Discoaster berggrenii at 2,292 m further confirmed the 7.0 Ma MFS [18] age assigned to the lower section.

\section{Palynostratigraphy}

Twenty-five palynomorphs were selected at $24 \mathrm{~m}$ intervals. The palynomorphs are well preserved and fairly diverse (Figure 6). These include Zonocostites ramonae, Monoporites annulatus, Sapotaceae, Retitricolporites irregularis, Pachydemites diederixi, Acrostichum aureum, Pteris spp, Laevigatosporites spp, Verucatosporites spp, Stereisporites spp, Cyperaceaepollis spp, Sapotaceae and Psilatricolporites crassus. Dinoflagellate cysts recorded are Selenopemphix spp, Polysphaeridium zoharyi and Leiosphaeridia spp. 


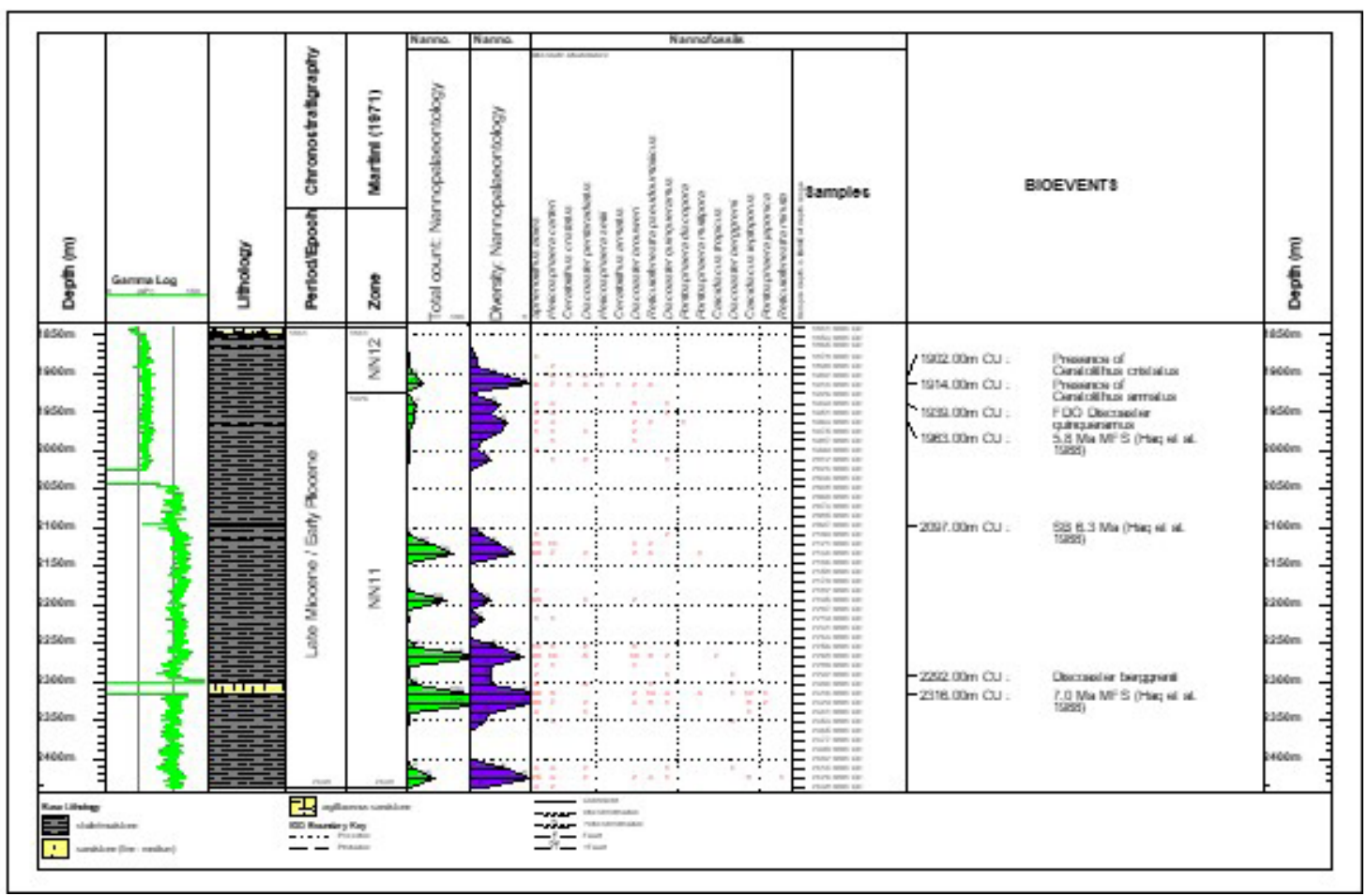

Figure 5: Calcareous nannofossil distribution chart of STEP-1 well.

Table 2: Calcareous nannofossils biostratigraphy of STEP-1 well

\begin{tabular}{lllll} 
Depth (m) & $\begin{array}{l}\text { Downhole occurrence of calcareous } \\
\text { nannofossils }\end{array}$ & $\begin{array}{l}\text { Age (Ma) } \\
\text { Haq et al. } \\
\mathbf{( 1 9 8 8 )}\end{array}$ & $\begin{array}{l}\text { NP zones } \\
\text { (Martini, } \\
\mathbf{1 9 7 1 )}\end{array}$ & $\begin{array}{l}\text { Inferred } \\
\text { relative } \\
\text { ages }\end{array}$ \\
\hline 1,841 & First sample analysed & & NN 12 & \\
1,902 & Presence of Ceratolithus cristatus & & & \\
1,914 & Presence of Ceratolithus cristatus & & & $\begin{array}{l}\text { Late } \\
\text { Miocene } \\
1,926\end{array}$ \\
\hline 1,939 & FDO: Discoaster quinqueramus & \multirow{2}{*}{5.8} & PN 11 & Pliocene \\
1,963 & Maximum flooding surface & & & \\
2,292 & FDO: Discoaster berggrenii & & & \\
2,316 & Maximum flooding surface, Presence: & 7.0 & & \\
$2,438 \mathrm{TD}$ & Discoaster quinqueramus & & & \\
\hline
\end{tabular}

The STEP-1 sediments are assigned to the section within the Pantropical Echitricolporites spinosus zone of Germeraad et al. [15] and the P800 zone of Evamy et al. [1]. The zone was further subdivided into P840 and P830 sub-zones. Details of the zone and sub-zone identified are represented in Tables 3 and 4, and explained briefly below.

\section{Zone: P800}

Sub-zone: P840

Interval: 1,829-2,204 m

Discussion: The top of this sub-zone is placed at $1,829 \mathrm{~m}$ of the first sample analysed. The base is defined by the quantitative occurrence of Cyperaceaepollis spp at 2,204 m. The P840 sub-zone is further confirmed and characterized by the presence of Stereisporites 


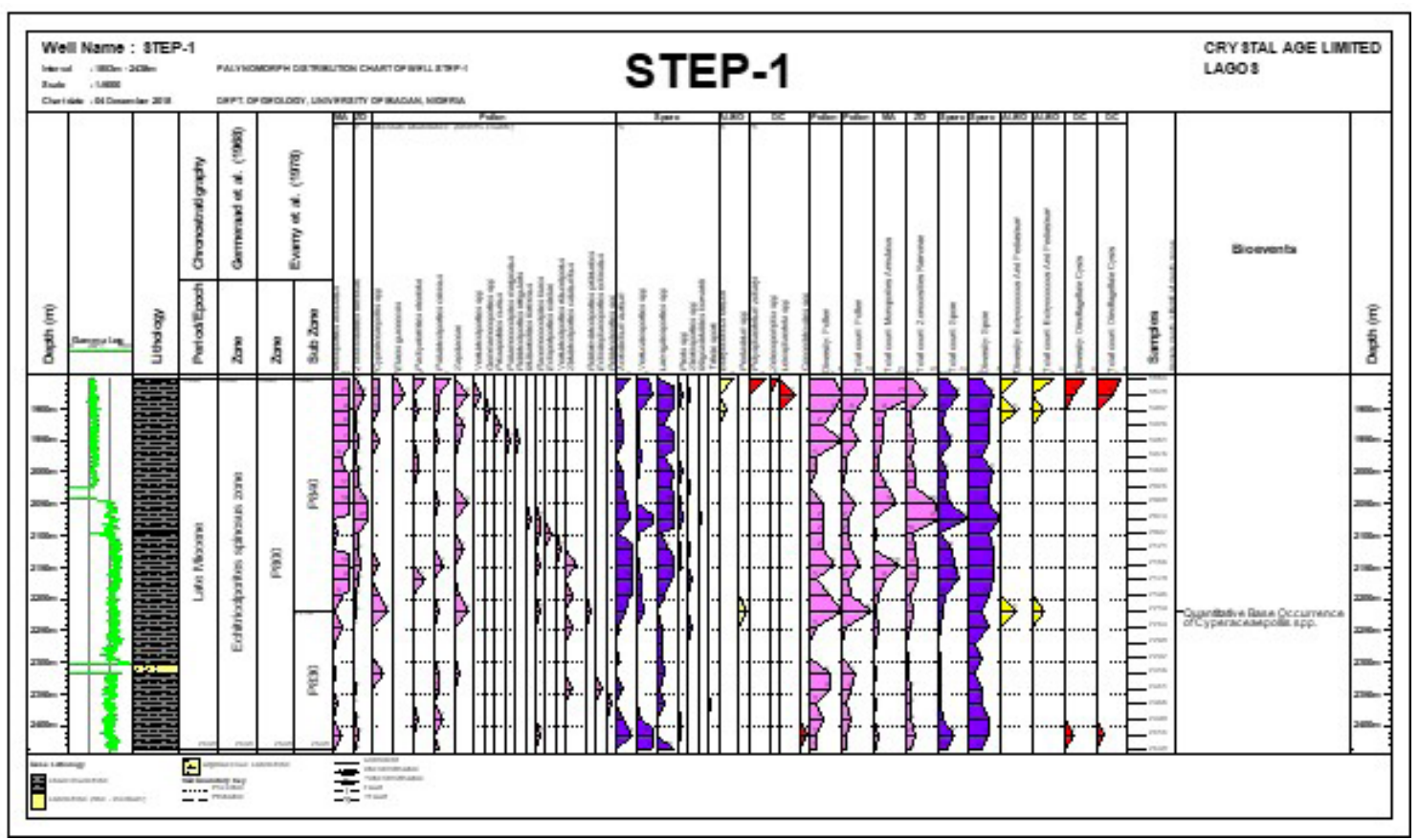

Figure 6: Palynomorphs distribution chart of STEP-1 well.

Table 3: Palynostratigraphy of STEP-1 well

\begin{tabular}{|c|c|c|c|c|c|}
\hline \multirow{2}{*}{$\begin{array}{l}\text { Depth }(\mathrm{m}) \\
\text { series }\end{array}$} & \multirow[t]{2}{*}{ Sub-series } & \multirow{2}{*}{$\begin{array}{l}\text { Gemeraad et al. } \\
\text { (1968) }\end{array}$} & \multicolumn{2}{|c|}{ Evamy et al. (1978) } & \multirow[t]{2}{*}{ Bioevents } \\
\hline & & & Zone & Sub-zone & \\
\hline \multirow[t]{6}{*}{ Miocene } & \multirow{6}{*}{$\begin{array}{l}\text { Late } \\
\text { Miocene }\end{array}$} & \multirow{6}{*}{$\begin{array}{l}\text { Echitricolporites } \\
\text { Spinosus zone }\end{array}$} & P 800 & P 840 & \multirow{6}{*}{$\begin{array}{l}\text { Quantitative base } \\
\text { occurrence of } \\
\text { Cyperaceaepollis spp }\end{array}$} \\
\hline & & & & & \\
\hline & & & & P 830 & \\
\hline & & & & & \\
\hline & & & & & \\
\hline & & & & & \\
\hline
\end{tabular}

spp, abundant mangrove pollen Zonocostites ramonae and Monoporites annulatus. The age assigned to this sub-zone is late Miocene.

2. Zone: P800

Sub-zone: P830

Interval: 2,204-2,438 m

Discussion: The top of this sub-zone is placed at 2,204 $\mathrm{m}$ defined by the quantitative base occurrence of Cyperaceaepollis spp while the base was not penetrated. This sub-zone is further characterized by the presence of Cyperaceaepollis spp, Stereisporites spp and Racemonocolpites hians. The age of this subzone is late Miocene.

\section{Age deductions}

The ages for this well were established using three bioevents (Table 5): these include recorded peak faunal abundance (MFS), sequence boundary (SB) and the occurrence of some index fossils such as Cyclammina cf. minima and Discoaster beggrenii. The chronostratigraphic position of STEP- 1 well is given in Table 6 .

\section{Palaeoenviroment of deposition}

1. The presence of some benthonic foraminifera such as Uvigerina auberiana, Lenticulina spp, Valvulineria spp, Haplophragmoides spp, Cyclamina cf. inina and Bolivina scalprata 


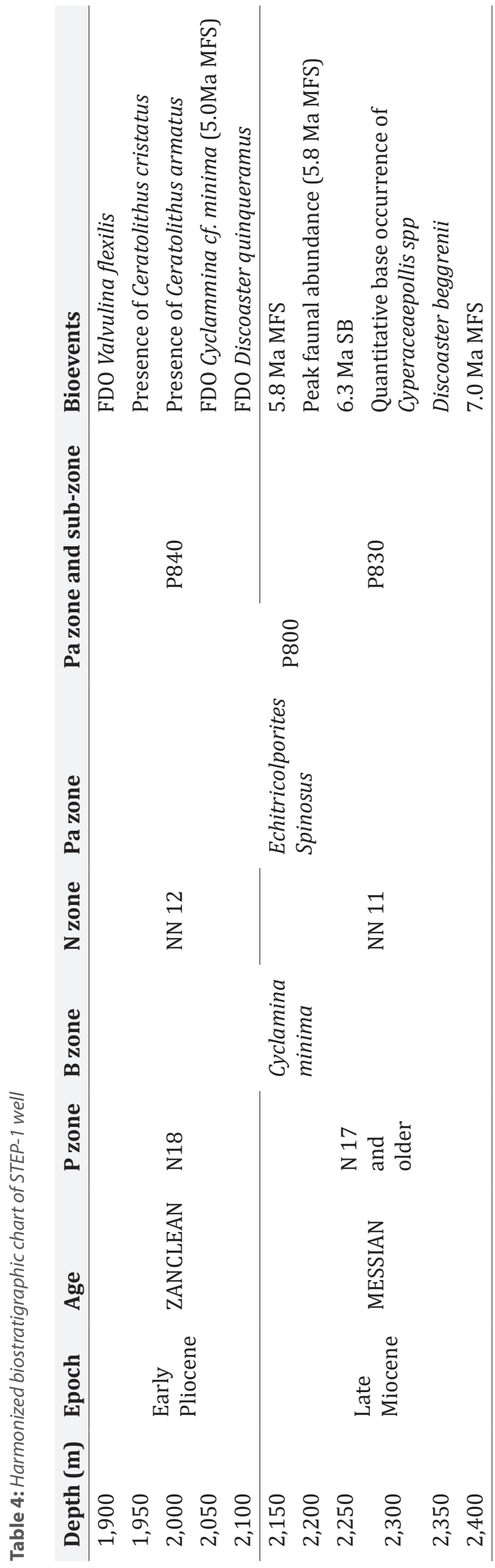

indicates a shallow marine environment (inner neritic).

2. With land-derived palynomorphs such as Monoporites annulatus, Laevigatosporites spp, Zonocostites ramonae, Acrostichum aureum, Pachydemites diederixi, Pteris spp, Striatricolpites catatumbus and Cyperaceaepollis spp (from 1,853-2,438 m). It can be deduced that the sediments were deposited within a shallow marine environment.

\section{Palaeoclimatic deductions}

Palynofossils are preserved mainly in continental basins. The characteristics of great quantity, wide distribution and different preserved lithofacies are the unique advantage of these fossils [19]. For this reason, palynomorphs are now very important for reconstructing palaeoclimatic conditions at the time of sediments deposition. The climate of an area is reflected by its vegetation type [20]. The three important palynomorphs used for this study are Monoporites annulatus, Zonocostites ramonae and Acrostichum aureum. Monoporites annulatus abundance is often used as an indicator of a large degree of landscape openness [21, 22], and increased aridity [23, 24]. Zonocostites ramonae has been used as an indicator for mangrove vegetation and hence, wet climatic condition [25]. Acrostichum aureum is used as an indicator of wet climatic condition [26].

From Figure 7, the dominance in abundance of Monoporites annulatus over the relative abundance of Acrostichum aureum favours a dry climatic condition for the interval 1,8532,048 $\mathrm{m}$. While the sediments are believed to have been deposited in the Savanna setting, interval 2,073-2,146 shows alternating wet and dry climate.

From Figure 8, the dominance in abundance of Acrostichum aureum over Monoporites annulatus from interval 2,170-2,438 $\mathrm{m}$ indicates a wet climatic condition; hence, they are of mangrove species, although interval 2,2432,265 m relatively shows alternating wet and dry climatic conditions. Figure 9 shows photomicrographs of foraminifera, calcareous nannofossil and Palynomorps recovered from the STEP-1 well. 
Table 5: Age deductions for STEP-1 well

\begin{tabular}{llll} 
Depth (m) & Age (Ma) & Microfossil & Bioevents \\
\hline 1,926 & 5.0 & Foraminifera & FDO Cyclammina cf. minima \\
1,963 & 5.8 & Nannofossils & Maximum flooding surface (MFS) \\
1,987 & 5.8 & Foraminifera & Peak faunal abundance (MFS) \\
2,097 & 6.3 & Nannofossils & Sequence boundary \\
2,316 & 7.0 & Nannofossils & MFS \\
\hline
\end{tabular}

Table 6: Chronostratigraphic position of STEP-1 well

\begin{tabular}{|c|c|c|c|c|}
\hline \multirow[b]{2}{*}{ Ma } & \multicolumn{4}{|c|}{ Standard chronostratigraphy } \\
\hline & Period & Epoch & Age/stage & This study \\
\hline 1 & \multirow{3}{*}{ Quaternary } & Holocene & Taranian & \multirow{11}{*}{ STEP-1 well } \\
\hline 2 & & \multirow{2}{*}{ Pleistocene } & Ionian & \\
\hline \multirow{2}{*}{3} & & & Calabrian & \\
\hline & \multirow{8}{*}{ Neogene } & \multirow{3}{*}{ Pliocene } & Gelasian & \\
\hline 4 & & & Piacenzian & \\
\hline 5 & & & Zanclean & \\
\hline 6 & & \multirow[t]{5}{*}{ Miocene } & Messinian & \\
\hline 7 & & & & \\
\hline 8 & & & Tortonian & \\
\hline 9 & & & 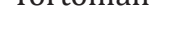 & \\
\hline 10 & & & & \\
\hline
\end{tabular}

\section{Summary and conclusions}

Foraminifera, calcareous nannofossils and palynomorph integrated biostratigraphic studies of the STEP-1 well in the offshore of Niger Delta Basin has resulted in the identification of biostratigraphic zones, determination of ages as wellas reconstruction of the palaeoenvironment and palaeoclimatic conditions. The presence of some benthonic foraminifera such as Uvigerina auberiana, Lenticulina spp, Valvulineria spp, Haplophragmoides spp, Cyclamina cf. inina and Bolivina scalprata indicates a shallow marine environment of deposition (inner neritic). Two nannofossil zones subdivided into late Miocene and early Pliocene are confirmed by the FDO of Discoster quinqueramus at $1,939 \mathrm{~m}$. The presence of Discoaster berggrenni at 2,292 m further confirmed the 7.0Ma MFS age assigned to the interval. The late Miocene age also corroborates with the appearance of the zonal marker, Cyclammina cf. minima, which was recorded

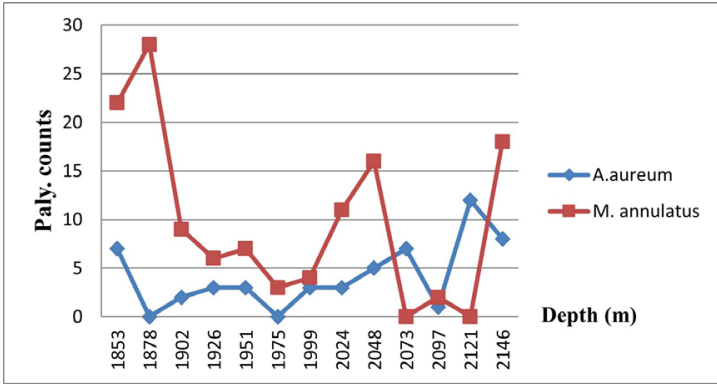

Figure 7: Plot of A. aureum/M. annulatus against depth $(1,853-2,146 m)$.

at $1,914 \mathrm{~m}$. The Palynological Zonation of the well and their stratigraphic distribution based on the zonation schemes of Germeraad et al. [15] and Evamy et al. [1] are broadly assigned to the Echitricolporites spinosus and P800 zone, respectively. The latter was further subdivided into P840 and P830 sub-zones. The assigned age is late-late Miocene. The boundary between P830 and P840 was at 2,204 m, which was marked by the Quantitative base 


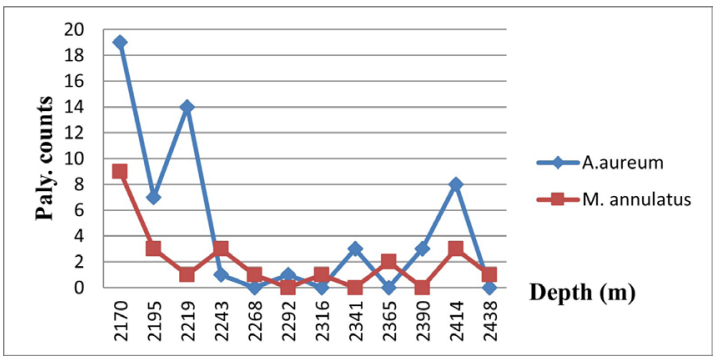

Figure 8: Plot of A. aureum/M. annulatus against depth $(2,170-2,438 m)$ occurrence of Cyperaceaepollis spp. The four major condensed sections identified within the studied section of the well which include intervals at 1,926, 1,987, 2,097 and 2,316 $\mathrm{m}$ have been dated 5.0, 5.8, 6.3 and $7.0 \mathrm{Ma}$, respectively, based on the identified foraminiferal and calcareous nannofossil zones with their equivalent bioevents. This study reveals that the well penetrated a major sedimentary formation in the Niger Delta, which conforms to the paralic
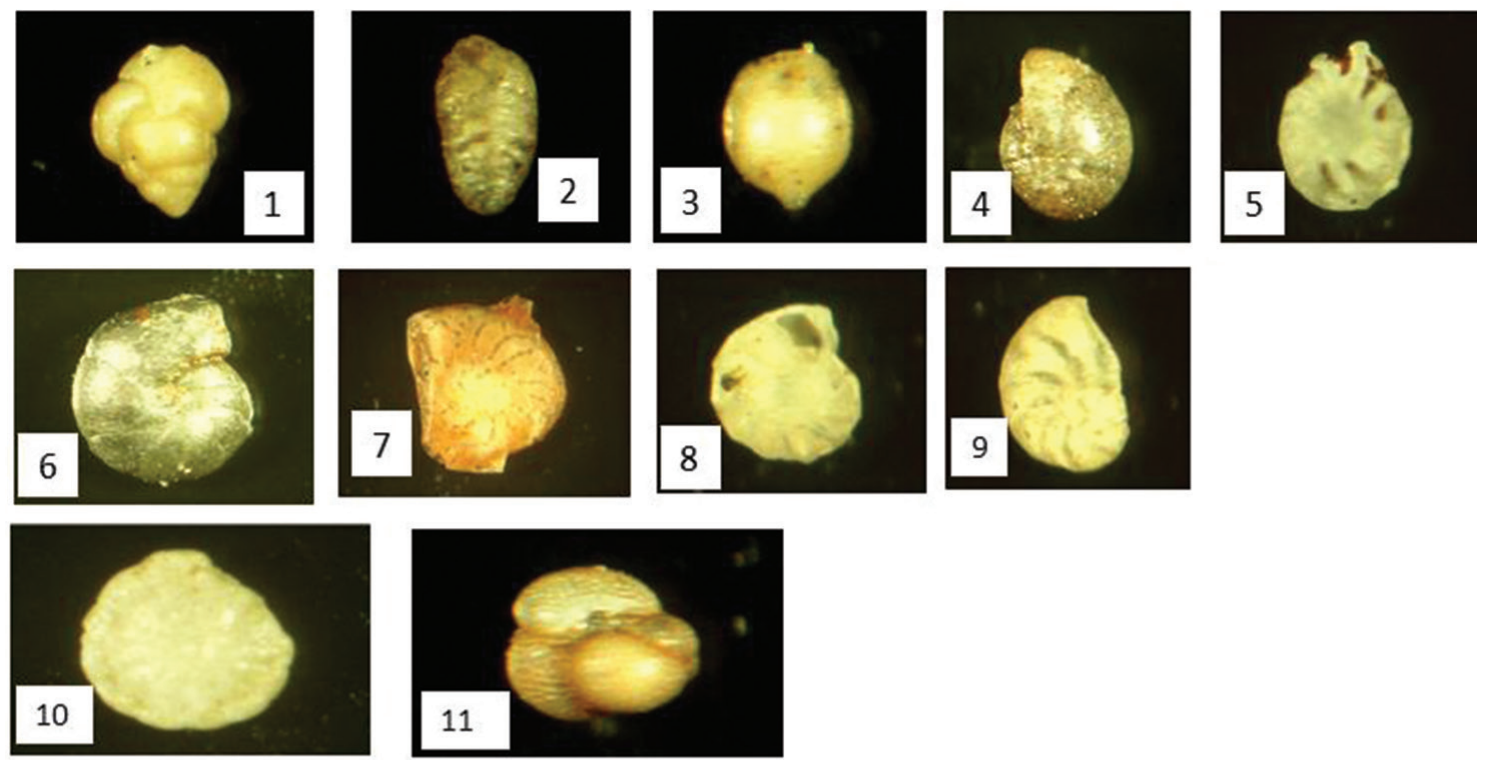

1. Uvigerina peregrina

4. Cyclammina cancellata

5. Lenticulina $s p$.

6. Cibicides $s p$

3. Lagenasp.
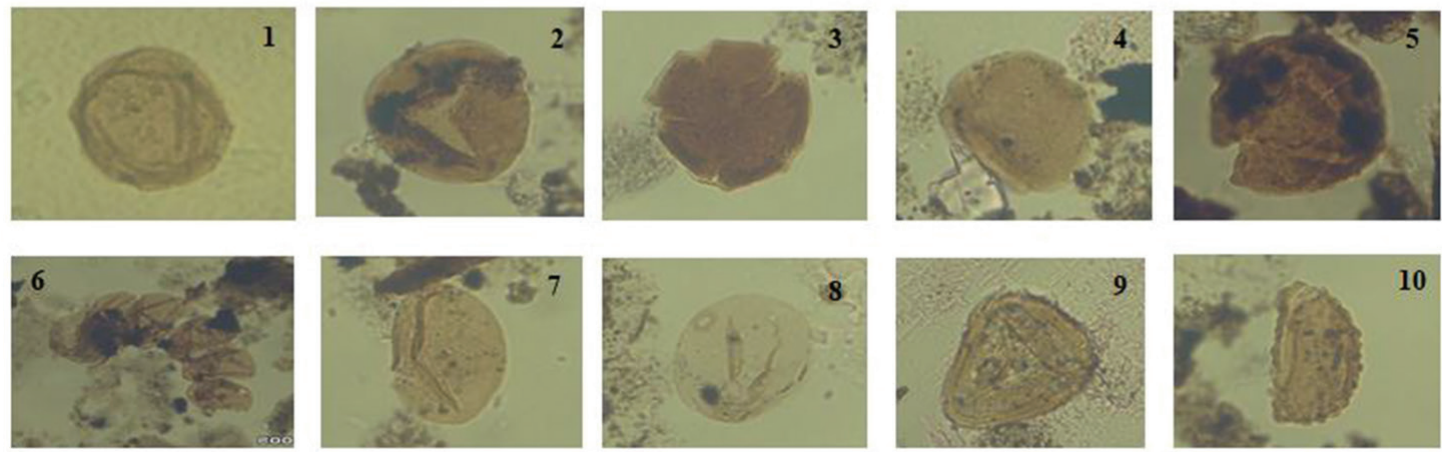

(1) Leiosphaeridia sp (2) Acrostichum aureum (3) Pachydermites diederixi (4\&5) Psilatricolporites crassus (6) Microforaminiferal wall linings (7) Laevigatosporites $s p$ (8) Monoporites annulatus (9) Pteris sp (10) Verrucatosporites sp

Figure 9: Continued 

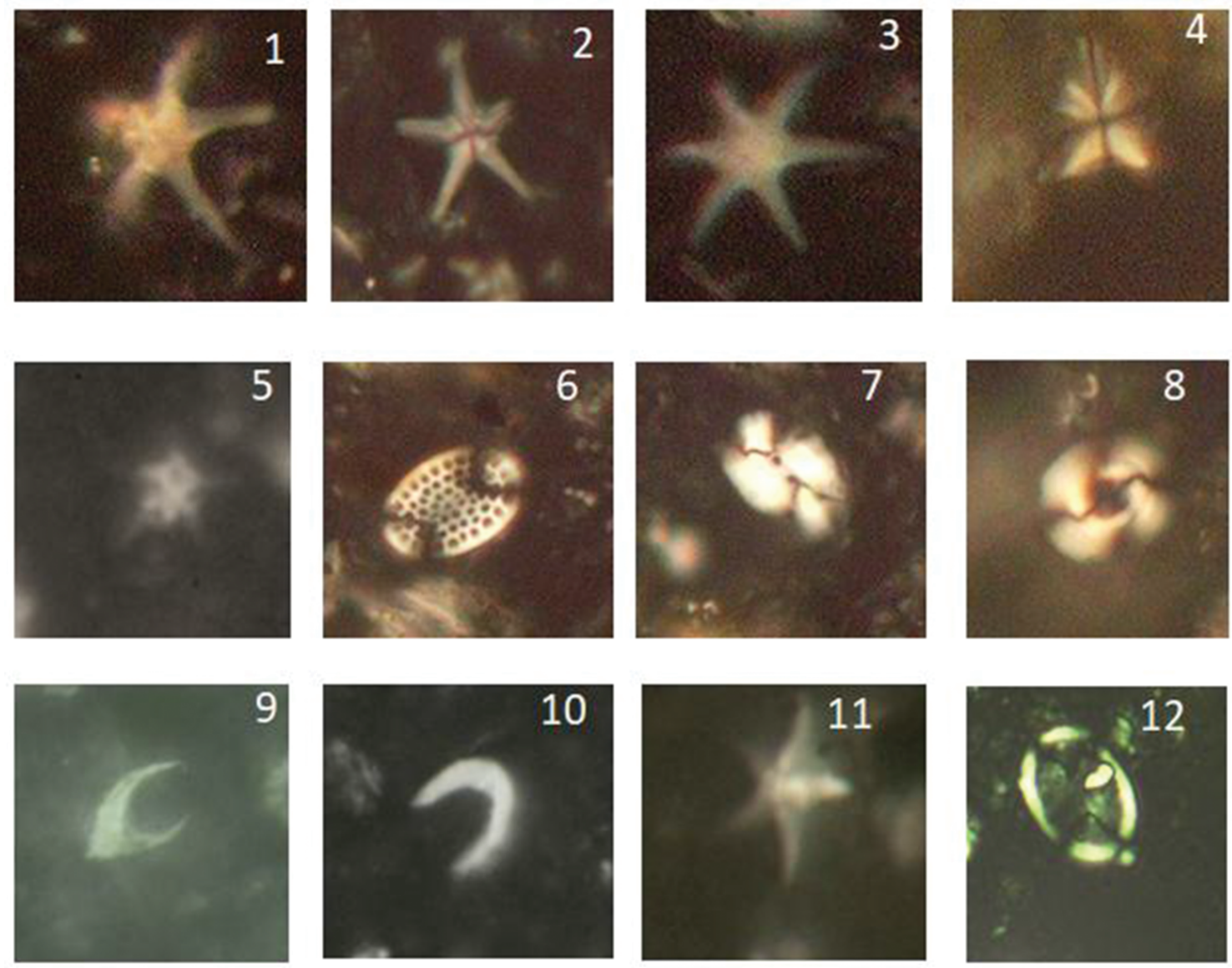

(1) Discoaster quinqueramus (2) Discoaster pentaradiatus (3) Discoaster brouweri

(4) Sphenolithus abies (5) Discoaster berggrenii (6) Pontosphaera multipora

(7) Helicosphaera carteri (8) Reticulofenestra pseudoumbilicus (9) Ceratolithus armatus (10)

Ceratolithus cristatus (11) Discoaster quinqueramus (12) Pontosphaera japonica

Figure 9: Photomicrographs of foraminifera, calcareous nannofossil and Palynomorps recovered from STEP-1 well.

sequence of Agbada Formation. The palynoflora Monoporites annulatus, Laevigatosporites $s p$. among others suggests a shallow marine environment of deposition, while the palaeoclimatic setting indicated both wet $(1,853-2,146 \mathrm{~m})$ and dry $(2,170-2,438 \mathrm{~m})$ conditions. The integration of the three microfossil groups for biostratigraphic studies has produced a detailed analysis in the recognition and interpretation of absolute biosignals.

\section{Acknowledgements}

The authors appreciate the efforts of Mrs Adebiyi E. Abidemi from Mosunmolu Ltd. for her support and the staff of Crystal Age Ltd, Lagos.

\section{References}

[1] Evamy, B.D., Harremboure, J., Kamerling, P., Knaap, W.A., Molloy, F.A., Rowlands, P.H. (1978): Hydrocarbon habitat of the Tertiary Niger Delta. American Association of Petroleum Geologists Bulletin, 62, pp. 277-298.

[2] Singh, A. (2008): Micropaleontology in petroleum exploration, Seventh International Conference and Exposition on Petroleum Geophysics Bulletin, pp. 288-294. 
[3] Fajemila, O.T. (2012): Foraminifera biostratigraphy and paleoenvironmental studies of two wells from offshore western Niger delta. Ife Journal of Science, 14(2), pp. 369-384.

[4] Sanuade, O.A. (2014): Calcareous nannofossil biostratigraphic analysis of well ' $\mathrm{K}-2$ ', deep offshore Niger Delta, Nigeria. Advances in Research, 2(12), pp. 696-711.

[5] Obaje, N.G. (2009): Geology and mineral resources of Nigeria, lecture notes in earth sciences 120. Journal of Geoscience and Environment Protection, DOI: 10.1007/978-3-540-92685-6.

[6] Aturamu, A.O., Ojo, A.O. (2015): Integrated biostratigraphic analysis of the Agbada Formation [Nep-1 Well] offshore, Eastern Niger-Delta Basin, Nigeria, Australian Journal of Biology and Environment Research, 2(1), pp. 1-14.

[7] Ukpabi, N., Osterloff, P.L., Oloto, I.N. (2014): Biostratigraphy studies of Miocene sediments in the onshore/offshore area, Niger Delta Basin, Nigeria. International Journal of Science Inventions Today, 3(4), pp. 330-345.

[8] Doust, H., Omatsola, E. (1990): Niger Delta. In: Divergent/passive Margin Basins, American Association of Petroleum Geologists Memoir 48, Edwards, J.D., Santogrossi, P.A., (eds.), American Association of Petroleum Geologists: Tulsa, pp. 239-248.

[9] Short, K.C., Stauble, A.J. (1967): Outline of the geology of Niger Delta. American Association of Petroleum Geologists Bulletin, 51, pp. 761-779.

[10] Avbovbo, A.A. (1978): Tertiary lithostratigraphy of Niger Delta. American Association of Petroleum Geologists Bulletin, 62, pp. 295-300.

[11] Blow, W.H. (1969): Late middle Eocene to recent planktonic foraminiferal biostratigraphy. In: Proceedings of the First International Conference on Planktonic Microfossils, Genova, Brönnimann, P., Renz, H.H. (eds.). E.J. Brill, pp. 199-442.

[12] Loeblich, A.R. Jr., Tappan, H. (1988): Foraminifera genera and their classification, Vol. 2. Van Nostrand Reinhold Company: New York, pp. 970.

[13] Berggreni, W.A., Kent, D.V., Swisher, C.C., Aubry, M. (1998): A revised Cenozoic geochronology and chronostratigraphy. DOI:10.2110/pec.95.04.0129

[14] Martini, E. (1971): Standard Tertiary and Quaternary Calcareous Nannoplankton Zonation. In: Proceedings II Planktic Conference, Rome, Farinacci, A. (ed.). 1970. 2, pp. 739-785.

[15] Germeraad, J.H., Hopping, C.A., Muller, J. (1968): Palynology of tertiary sediments from tropical areas. Review of Palaeobotany and Palynology, 6, pp. 189-346.

[16] Hardenbol, J., Thierry, J., Farley, M.B., Jacquin, T., de Gracuabsjt, P., Vail, P.R. (1998): Mesozoic and Cenozoic sequence chronostratigraphic framework of European basins. In: Mesozoic and Cenozoic sequence stratigraphy of European basins, De Graciansky, P.C., Hardenbol, J., Jacquin, Th., Vail, P.R. (eds.). SEPM Special Publication 60.

[17] Okada, H., Bukry, D. (1980): Supplementary modification and introduction of code numbers to the low-latitude coccolith biostratigraphic zonation [Bukry, 1973, 1975]. Marine Micropaleontology, 5, pp. 321-325, DOI: 10.1016/0377-8398[80]90016-X.

[18] Haq, B.V.J., Hardenbol, J., Vail, P.R. (1988): Mesozoic and Cenozoic chronostratigraphy and eustatic cycles. In: Sea level change - an integrated approach, Wilgus et al. (eds.), SEPM Special Publication, No. 42, pp. 71-108.

[19] Zhao, J., Wan, X.Q., Xi, D.P., Jing, X., Li, W., Huang, Q.H., et al. (2014): Late cretaceous palynology and paleoclimate change: Evidence from the SK1 [South] core, Songliao Basin, NE China. Science China Earth Sciences, 57(12), pp. 2985-2997, DOI: 10.1007/ s11430-014-4975-4.

[20] Samant, B., Phadtare N.R. (1997). Stratigraphic palynoflora of the Early Eocene Rajpardi lignite, Gujarat and the lower age limit of the Tarkeshwar Formation of South Cambay Basin, India. Palaeontographica, B, 245, pp. 1-108.

[21] Joly C, Barille L, Barreau M, Mancheron A, Visset L. (2007): Grain and annulus diameter as criteria for distinguishing pollen grains of cereals from wild grasses. Review of Palaeobotany and Palynology, 146, pp. 221-233.

[22] Schüler, L., Behling H. (2011): Poaceae pollen grain size as a tool to assess palaeoecological grassland dynamics in South America. Veget Hist Archaeobot, 20, pp. 83-96.

[23] Salgado-Labouriau M.L., Rinaldi M., (1990): Measurements of gramineae pollen of the Venezuelan mountains. Revista Brasileira de Biologia, 50, pp. 115-122.

[24] Behre K.E. (1981): The interpretation of anthropogenic indicators in pollen diagrams. Pollen Spores, 23, pp. 225-245.

[25] Massini García, J.L., Jacobs, B.F., Pan, A., Tabor, N., Kappelman, J. (2006): The occurrence of the fern Acrostichum in Oligocene volcanic strata of the 
Northwestern Ethiopian Plateau. International

Journal of Plant Science, 167(4), pp. 909-918.

[26] Morley, R.J. (1995): Biostratigraphy characterization of systems tracts in tertiary sedimentary basins. Proceedings of the International Symposium on Sequence Stratigraphy, Jakarta, S.E. Asia, 1, pp. 49-71. 